\title{
Neuropeptide $Y$
}

National Cancer Institute

\section{Source}

National Cancer Institute. Neuropeptide Y. NCI Thesaurus. Code C685.

Neuropeptide $\mathrm{Y}(36 \mathrm{aa}, \sim 4 \mathrm{kDa}$ ) is encoded by the human NPY gene. This protein is involved in feeding behavior. 